\title{
PELATIHAN PEMASARAN ONLINE DAN PENGEMBANGAN APLIKASI BERBASIS ANDROID UNTUK PENGEMBANGAN KEWIRAUSAHAAN ALUMNI
}

\author{
Titis Shinta Dhewi $^{{ }^{*}}$, Syihabudhin ${ }^{2}$, Afwan Hariri Agus Prohimi ${ }^{3}$, Dediek Tri Kurniawan ${ }^{4}$ \\ $1,2,3,4$ \\ Departemen Manajemen, Universitas Negeri Malang, Indonesia \\ E-mail: ${ }^{1)}$ titis.shinta.fe@um.ac.id
}

\begin{abstract}
Abstrak
Penetrasi internet di Indonesia telah menjadi peluang bagi pelaku usaha dalam meningkatkan penjualannya melalui pemasaran online. Khusus dalam bidang pemasaran, era digital saat ini pemasaran online menjadi tren yang sangat tinggi di kalangan masyarakat. Di tengah perkembangan teknologi digital, tim pengabdian Jurusan Manajemen Universitas Negeri Malang (UM) mengadakan pelatihan dengan pendekatan coaching untuk pemasaran digital. Target peserta dalam pengabdian ini adalah alumni jurusan manajemen UM yang memiliki dan sedang menjalankan bisnis. Pelatihan ini dilaksanakan pada dua tahap dengan topik (1) pemasaran digital dan (2) bisnis digital dan digital transformation. Untuk keberlanjutannya, tim pengabdian juga mengembangkan platform aplikasi berbasis android yang ditujukan kepada alumni jurusan manajemen UM.
\end{abstract}

Kata kunci: Pemasaran Online, Android, Kewirausahaan, Alumni.

\begin{abstract}
Internet penetration in Indonesia has become an opportunity for business actors to increase their sales through online marketing. Especially in the field of marketing, the current digital era online marketing is becoming a very high trend among the public. In the midst of the development of digital technology, the team from Department of Management, Universitas Negeri Malang (UM) held training with a coaching approach for digital marketing. The target participants in this service are alumni of the management department on UM who own and are running a business. This training was carried out in two stages with the topics of (1) digital marketing and (2) digital business and digital transformation for its sustainability, the service team also developed an android-based application platform for the alumni of the management department on UM.
\end{abstract}

Keywords: Online Marketing, Android, Entrepreneurship, Alumni.

\section{PENDAHULUAN}

Pertumbungan ekonomi digital di Indonesia terus berkembang signifikan. Menurut data dari Asosiasi Penyelenggara Jasa Internet Indonesia, tercatat jumlah pengguna internet di Indonesia sebanyak 171,1 juta pengguna pada 2018 (APJII, 2018). Dari data yang didapat dari e-Conomy SEA 2019, yaitu survei yang dilakukan oleh Google, Tamasek, dan Bain \& Company (2016), perekonomian digital Indonesia merupakan yang terbesar di Asia Tenggara yang diprediksi $\$ 40$ miliar dan diprediksi mencapai 130 miliar pada 2025. Angka tersebut jauh dari negara ASEAN lainnya seperti Malaysia (\$11 miliar), Thailand (\$16 miliar), dan Vietnam (\$12 miliar). Dalam survei tersebut, pengguna internet di Indonesia tahun 2019 mencapai 152 juta pengguna. 
Penetrasi internet di Indonesia telah menjadi peluang bagi pelaku usaha dalam meningkatkan penjualannya melalui pemasaran online. Dunia industri berkembang menjadi dunia digital (Parviainen et al., 2017). Pandemi COVID-19 telah mempercepat fenomena ini (Priyono et al., 2020). Pemasaran online merupakan kegiatan penyebaran, pembelian, penjualan, pemasaran barang dan jasa melalui sistem elektronik seperti internet atau televisi, atau jaringan komputer lainnya (Nugroho et al., 2014). Ada beberapa media digital yang berpotensi digunakan sebagai pemasaranproduk seperti website, content marketing, sosial media, search engine optimization (SEO), Google ads, email marketing (Irawan et al., 2019) Penggunana media digital seperti media sosialmemiliki pengaruh yang signifikan terhadap peningkatan trafik situs web serta peningkatan penjualan online (Saragih \& Tarigan, 2020).

Khusus dalam bidang pemasaran, era digital saat ini pemasaran online menjadi tren yang sangat tinggi di kalangan masyarakat. Apalagi di masa pandemic yang sudah berlangsung hampirsetahun ini. Sebagaimana dikutip oleh Exabytes, sebuah perusahaan layanan hosting di Indonesia, jumlah pelanggan E-commerce mengalami peningkatan hingga 38,3\% selama masa Pandemi Corona COVID-19 sampai dengan kurun waktu Juli 2020. Exabytes menyebutkan, ada titik cerahdi balik situasi ekonomi yang perlahan merosot di mana perkembangan teknologi bisa melahirkanpeluang baru khususnya di bidang $E$ Commerce. Ada kenaikan yang cukup besar dari masyarakat mendaftarkan websitenya untuk keperluan berwirausaha. Pemanfaatan teknologi digital untuk bisnis khususnya skala UMKM sudah menjadi keharusan. Sebagaimana dilansir laman Kominfo.go.id (2020) pencanangan gerakan UMKM Go Online yang bekerja sama dengan marketplace dan ekosistem bertujuan memfasilitasi dan memberikan kesempatan pada UMKM di berbagai daerah untuk siap bersaing di pasar yang lebih luas.

Secara sederhana pemasaran online adalah strategi pemasaran yang menggunakan media internet. Pemasan online memungkinkan konsumen mampu dengan mudah mengakses informasidengan cepat terhadap produk atau jasa yang ditawarkan sehingga kemungkinan pembelian yangdilakukan oleh konsumen terhadap produk tersebut juga semakin besar (Taylor \& England, 2006). Pemasaran online dapat dilakukan dengan memanfaatkan media sosial, website, email, maupun aplikasi berbasis Android. Dengan kata lain pemasaran online dapat fleksibel mengikutiperkembangan pasar dimana yang dapat dilakukan sekarang adalah menggunakan strategi pemasaran online yang relevan dan sejauh mana metode pemasaran ini dapat berkembang.

Pemasaran online dengan basis internet merupakan ruang global yang memungkinkan siapa saja bisa masuk ke dalamnya,tanpa harus terhambat oleh batasan ruang dan waktu. Karena saat ini orang bisa mengakses internet kapan saja dan di mana saja. Peluang inilah yang harus dimanfaatkan oleh para lulusan perguruan tinggi, termasuk oleh lulusan Prodi S1 Manajemen FE UM yang juga banyak memilikiusaha mandiri, baik sejak mereka masih mahasiswa maupun stelah lulus kuliah. Berdasarkan uraian tersebut, tim pengabdian dari jurusan Manajemen Universitas Negeri Malang mengadakan pelatihan pemasaran onlin untuk alumni jurusan Manajemen Universitas Negeri Malang. Pengabdian ini bertujuan mendorong peningkatan kompetensi kewirausahaan pada alumni dalam menjalankan bisnisnya. Pengabdian ini dilakukan dengan menggunakan metode coaching yang dilaksanakan di Universitas Negeri Malang. Selain itu, dalam rangka peningkatan kolaborasi dengan alumni perlu adanya sebuah plaform untuk peningkatan kolaborasi antar 


\section{PORTAL RISET DAN INOVASI PENGABDIAN MASYARAKAT (PRIMA) \\ VOLUME 1 ISSUE 1 (2021)}

alumni serta dengan jurusan manajemen FE UM dalam jangka panjang. Oleh karena itum pengabdian ini juga berupaya merancang plaform berbasi android bagi alumni yang bisa diakses kapan saja dan dimana saja.

\section{METODE PENELITIAN}

Target kegiatan coaching ini adalah alumni jurusan manajemen Universitas Negeri Malang yang sedang dan memiliki bisnis/usaha. Pengabdian ini mengunakan metode coaching dalam pelatihan ini. Coaching merupakan sebuah program pembimbingan secara intensif dan tersistematis dalam rangka membantu seseorang meningkatkan kemampuannya dalam menyelesaikan suatu permasalah yang dihadapinya (Widodo et al., 2015) Coaching sering diimplementasikan dalam bidang pengembangan profesionalisme dalam bidang pekerjaanya. Metode pelaksanaan coaching dalam pengabdian ini akan mengkombinasikan antara pelatihan secara online dan offline. Metode pembelajaran yang dikembangkan juga akan dilakukan denganragam metode untuk mendukung tujuan dan luaran dari kegiatan. Kegiatan ini akan dipusatkan di Fakultas Ekonomi Universitas Negeri Malang. Adapun rincian dari pelaksanana kegiatan coaching.

1. Persiapan:

a) Penyusunan proposal

b) Identifikasi kebutuhan pelaksanaan program pengabdian masyarakat

c) Koordinasi dengan seluruh pihak yang terlibat.

d) Penyusunan desain program, tujuan, dan indikator pengukuran keberhasilan program

e) Sosialisasi dan pembukaan pendaftaran program coaching.

f) Pendataan peserta coaching seperti nama, usia, dan jenis produk dihasilkan agar menjadidatabase tim pelaksana untuk merancang kegaitan yang efektif.

2. Pelaksanaan Program:

a) Tahap awal adalah penerimaan peserta (pendaftaran) sebanyak 20 orang dan pendataan peserta yang masuk dan melakukan komunikasi mengenai rancangan kegiatan.

b) Setelah pendaftaran, peserta yang dinyatakan sesuai dengan target kegiatan dihubungi untuk informasi seluruh kegiatan/aktivitas.

c) Program kegiatan coaching clinic pemasaran online akan dilakukan dengan lebih banyak diisi dengan pemaparan diskusi dan diskusi. Pada coaching ini membuat konten pemasaran online yang akan didampingi oleh instruktur dan pendamping untuk menghasilkan sebuah konten pemasaran online.

d) Pada tahap berikutnya, pelaksana kegiatan akan memperkenalkan media pembelajaran berbasis android yang diberi nama "MARKOL" yang akan membantu kegiatan selanjutnya. Selain itu, kegiatan coaching clinic ini menjadi kesempatan uji coba "MARKOL" untuk mendukung kegiatan ini.

e) Program pendampingan untuk membuat output nyata sebuah konten pemasaran online.

3. Evaluasi Program:

a) Mencatat permasalahan-permasalahan yang muncul selama proses pelatihan.

b) Mengevaluasi antusias peserta, baik itu umpan balik dan respon dari peserta pelatihan. 
c) Membuat notulensi pelaksanaan kegiatan.

\section{HASIL DAN PEMBAHASAN}

Untuk meningkatkan pemahaman pemasaran online atau digital marketing, dosen jurusan manajemen Universitas Negeri Malang mengadakan pengabdian masyarakat dengan target alumni jurusan manajemen UM tentang pelatihan kepada alumni terkait pemasaran online tersebut. Tujuan dari kegiatan ini adalah meningkatkan kolaborasi dengan alumni dan mendukung penguatan entrepreneurship pada kalangan alumni. Dalam pelatihan ini, pemasaran online adalah topik utama dalam pelatihan. Alumni dibekalai dengan pengetahuan terkait Digital Marketing, cara meningkatkan engagement, serta cara ameningkatkan peluang bisnis menggunakan aplikasi pemasaran online.

Kegiatan ini dimulai dengan mendata sejumlah 20 alumni Jurusan Manajemen FE UM yang sudah memiliki usaha dalam kurun waktu minimal 6 bulan serta berdomisili di Malang Raya. Alumni mulai melakukan pendaftaran sesuai form yang disediakan sehingga dapat diidentifikasi jenis usaha bisnis yang dijalankan. Bidang bisnis yang dijalankan oleh peserta sangat beragam seperti kuliner, dagang, dan jasa. Ditengah pandemi COVID-19, tim pelaksana pelatihan ini memutuskan menggunakan media Zoom meetings dalam pelaksaannya. Pelatihan ini didadakan pada bulan Oktober dan November 2021 dengan beberapa topik pelatihan seperti: (1) digital marketing, (2) implementasi digital marketing, (3) Membangun Bisnis, (4) Peluang dari digital marketing, dan (5) Digital bisnis dan digital transformation.

Setelah itu diadakan diskusi online dengan para peserta untuk menggali lebih dalam permasalahan masing-masing usaha bisnis yang dijalankan. Diskusi selama 2 tahap tersebut diketahui terdapat permasalahan: (1) Cara pemasaran online yang tepat, (2) Belum mengetahui cara berinteraksi yang tepat dengan konsumen maupun calon konsumen, dan (3) Perlu diciptakan suatu media pemasaran online yang tepat.

Sesi pelatihan diisi langsung oleh dosen manajemen yaitu Dr. Titis Shinta Dhewi, S.P, M.M. dan Dediek Tri Kurniawan, S.E., M.M. Di tengah pandemi COVID-19, pelatihan ini dilakukan melalui aplikasi Zoom Meeting. Pelatihan tidak hanya fokus pada kajian ilmu dan teoritis saja tetapi juga bagaimana implementasinya di dunia nyata. Untuk pemaparannya, tim pelaksana menggunakan metode-metode presentasi (presentasi methods) yaitu metode pelatihan dimana orang-orang yang dilatih merupakan penerima informasi pasif. Setiap sesi diberikan kesempatan untuk sesi tanya jawab. Kesempatan itu digunakan oleh beberapa alumni yang sedang menjalankan usaha untuk sekedah berbagi pengalaman terkait permasalahan yang dihadapi.

Berikut adalah poster kegiatan coaching clinic pemasaran online: 


\section{PORTAL RISET DAN INOVASI PENGABDIAN MASYARAKAT (PRIMA) \\ VOLUME 1 ISSUE 1 (2021)}

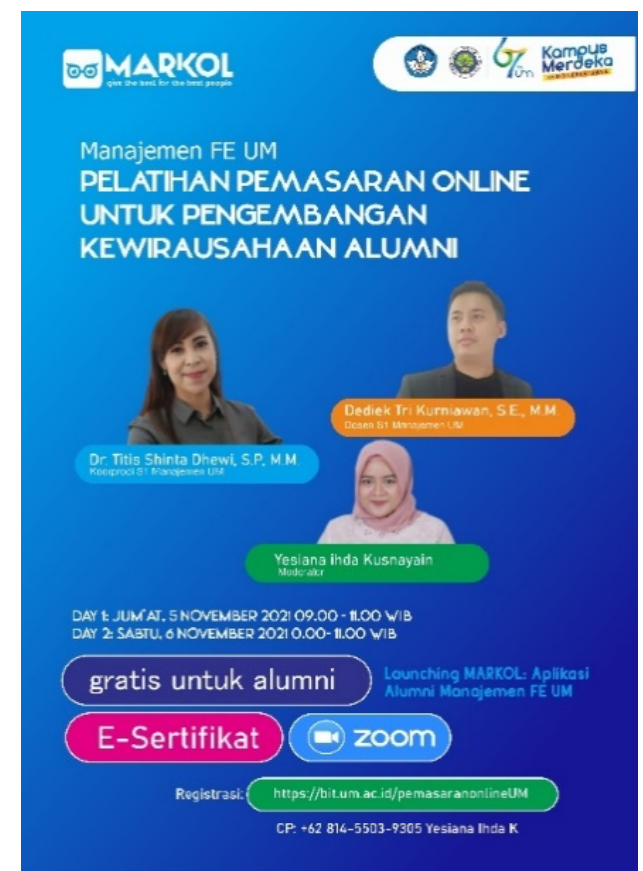

Gambar 1 Poster Pelatihan Pemasaran Online

\subsection{Coaching Tahap pertama}

Pada kegiatan tahap pertama, tim pelaksana menfokuskan penguatan pemahaman mengenai digital marketing daan implementasinya. Kegiatan pertama diisi oleh Dr. Titis Shinta Dhewi, S.P, M.M. yang merupakan dosen jurusan manajemen UM yang fokus pada bidang pemasaran. Kegiatan dimulai dengan pemaparan dari masing-masing bisnis yang dijalankan dan bagaimana kondisi bisnis yang sedang dijalankan. Dari coaching pertama, peserta tidak hanya diberikan kajian teoritis untuk bidang pemasaran digital tapi peserta diajak untuk berbagai pengalaman dalam praktek dan implementasi pada masing-masing bisnisnya. Hal ini mendorong sharing antar alumni yang memiliki bisnis untuk berbagi pengalamannya. Dari penyampaian peserta, tantangan dalam implementasi digital marketing adalah pemilihan media yang efektif karena terkadang banyak pemasaran digital yang dilakukan tidak sesuai dengan target pasar yang dituju. Berdasarkan hal-hal tersebut maka mulai disusun suatu aplikasi pemasaran online yang sesuai dengan kebutuhan usaha bisnis alumni.

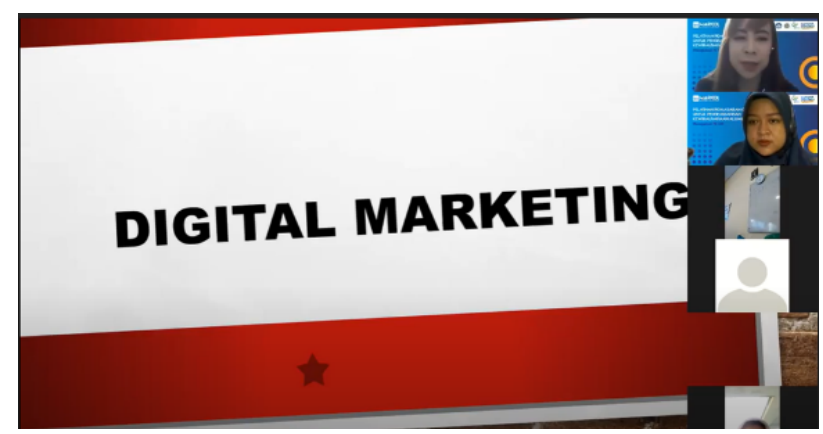

Gambar 2 Pelatihan Tahap Pertama "digital marketing and implemention" 


\subsection{Coaching Tahap Kedua}

Coaching pada tahap kedua dilaksanakan oleh Dediek Tri Kurniawan, S.E., M.M dengan topik digital bisnis dan transformasi digital. Bisnis telah berkembang dan mengarah menjadi digital yang juga dipercepat oleh pademi COVID-19. Dalam coaching ini, peserta diajak untuk mempertimbangkan penggunaan teknologi digital dalam meningkatkan efisiensi bisnis seperti kegiatan operasional dan pemasaran. Menurut Heavin and Power (2018), tujuan utama transformasi digital adalah untuk menyelesaikan tantangan mengenai efisiensi dan efektivitas, sementara Hess, Benlian, Matt, dan Wiesböck (2016) menyatakan bahwa perusahaan yang tidak mengembangkan dan menerapkan strategi digital transformation dengan cepat tidak mungkin mengimbangi dan bersaing. Dalam coaching ini, peserta diharapkan dapat mendorong penggunaan/adopsi teknologi digital dalam bisnis mereka.

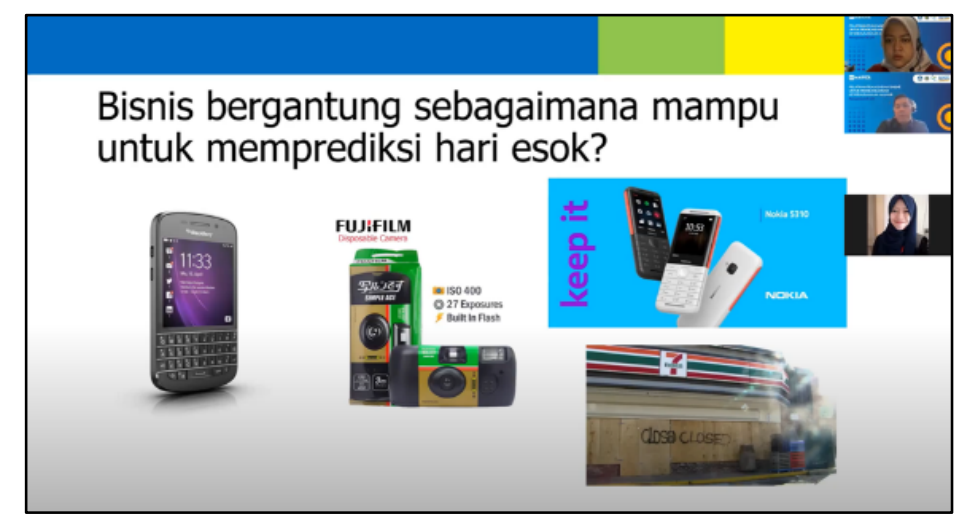

Gambar 3 Pelatihan Tahap Kedua "digital business and digital transformation"

\subsection{Pembuatan Aplikasi untuk Alumni}

Pada program pelatihan ini, tim pelaksana juga menyempatkan mengenalkan produk digital yang tengah dikembangkan untuk para alumni dalam meningkatkan kolaborasi. Produk digital ini diberi nama "Markol" atau singkatan dari "Marketing Online". Sebuah platform yang nantinya akan menghubungkan alumni jurusan manajemen UM. Produk ini diharapkan mampu meningkatkan kolaborasi antar civitas UM dan alumni ataupun sesama alumni. Program Pengabdian Masyarakat ini diawali dengan menghasilkan dan menawarkan sebuah aplikasi pemasaran online berbasis Android yang bernama "MARKOL" yang dikembangkan oleh tim. Fokus kegiatan program ini adalah mendampingi dan memberikan pelatihan aplikasi pemasaran online "MARKOL" kepada alumni prodi S1 Manajemen yang telah memiliki usaha sendiri yang diharapkan mampu meningkatkan penjualan produk mereka.

Markol merupakan sebuah platform sosial yang disediakan khusus bagi seluruh Alumni yang bertujuan sebagai wadah interaksi digital antar Alumni Jurusan Manajemen UM. Platform ini juga menyediakan fitur e-commerce yang memungkinan seluruh alumni jurusan manajemen UM bisa saling menjual produk dan bertransaksi melalui media ini. Adanya aplikasi ini diharapkan dapat meningkatkan kualitas hubungan antar Alumni juurusan manajemensecara personal dan professional. Aplikasi ini membantu dalam berbagai aktivitas seperti: (1) Membuat kiriman status, tulisan, agenda/acara, mencari 


\section{PORTAL RISET DAN INOVASI PENGABDIAN MASYARAKAT (PRIMA) \\ VOLUME 1 ISSUE 1 (2021)}

mitra; (2) Mendapatkan kabar dan bertukar pengalaman dengan alumni lainnya; (3) Menemukan acara/aktivitas yang diadakan oleh sesama Alumni jurusan manajemen UM; (4) alumni masih dapat mengetahui event yang diadakan oleh jurusan manajemen UM, (5) Sebagai pusat data untuk alumni, (6) Memverifikasi data Alumni; dan (7) menangkap peluang kolaborasi di masa depan.

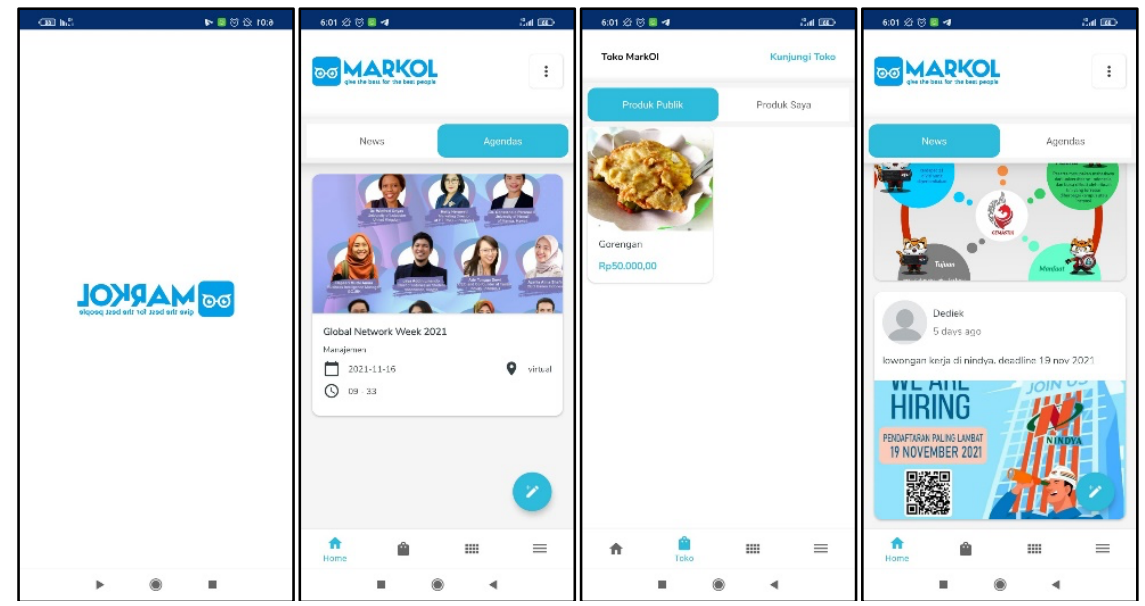

Gambar 4 Tampilan Platform "MarKol"

\section{KESIMPULAN}

Berdasarkan hasil kegiatan pelatihan menggunakan metode coaching, pemasaran online merupakan solusi dalam menjangkau pasar lebih luas serta meningkatkan efisiensi biaya. Pemasaran online mampu menekan biaya marketing yang cinderung cukup besar bila dilakukan secara kovensional. Secara umum, hasil kegiatan pendampingan menggunakan Aplikasi Zoom memberikan penambahan wawasan tentang pemasaran digital dan kompetensi penggunaan teknologi untuk menjalankan bisnis. Dalam keberlanjutan kolaborasi dengan alumni, tim pengabdian membangun platform "MARKOL" yang hanya bisa diakses oleh alumni. Platform ini bertujuan sebagai wadah interaksi digital antar Alumni Jurusan Manajemen UM. Platform ini juga menyediakan fitur e-commerce yang memungkinan seluruh alumni jurusan manajemen UM bisa saling menjual produk dan bertransaksi melalui media ini.

\section{DAFTAR PUSTAKA}

APJII (Asosiasi Penyelenggara Jasa Internet Indonesia). (2018). Hasil Survei Penetrasi dan Perilaku Pengguna Internet 2018. https://www.apjii.or.id/content/read/39/410/Hasil-Survei-Penetrasi-dan-PerilakuPengguna-Internet-Indonesia-2018

Irawan, D. J., Adriantantri, E., Limpraptono, Y., \& Nurcahyo, E. (2019). PEMASARAN ON-LINE PENJUALAN KOMPUTER SECOND. Jurnal Mnemonic, 2(2). https://doi.org/10.36040/mnemonic.v2i2.85

Google, Tamasek, \& Bain \& Company. (2016). e-Conomy SEA 2019. https://www.blog.google/documents/47/SEA_Internet_Economy_Report_2019.pdf/ 
Heavin, C., \& Power, D. J. (2018). Challenges for digital transformation-towards a conceptual decision support guide for managers. Journal of Decision Systems, 27. https://doi.org/10.1080/12460125.2018.1468697

Hess, T., Benlian, A., Matt, C., \& Wiesböck, F. (2016). Options for formulating a digital transformation strategy. MIS Quarterly Executive, 15(2). https://doi.org/10.4324/9780429286797-7

Kominfo. (2020). Dukung UMKM Go Online, Kominfo Kurangi Kesenjangan Talenta Digital. https://kominfo.go.id/content/detail/27427/dukung-umkm-go-online-kominfokurangi-kesenjangan-talenta-digital/0/berita_satker

Nugroho, A., Daru, A. F., \& Adhiwibowo, W. (2014). Pengembangan Pemasaran Online Usaha Kerajinan Enceng Gondok dan Pandan di Desa Lopait Kecamatan Tuntang Kabupaten Semarang. Jurnal Transformatika, 12(1). https://doi.org/10.26623/transformatika.v12i1.87

Parviainen, P., Tihinen, M., Kääriäinen, J., \& Teppola, S. (2017). Tackling the digitalization challenge: How to benefit from digitalization in practice. International Journal of Information Systems and Project Management, 5(1). https://doi.org/10.12821/ijispm050104

Priyono, A., Moin, A., \& Putri, V. N. A. O. (2020). Identifying digital transformation paths in the business model of smes during the covid-19 pandemic. Journal of Open Innovation: Technology, Market, and Complexity, 6(4). https://doi.org/10.3390/joitmc6040104

Saragih, L., \& Wico J Tarigan. (2020). Keputusan Pembelian On - Line melalui Sosial Media Pemasaran Usaha Mikro Dan Kecil Sebuah pendekatan literatur. Manajemen : Jurnal Ekonomi, 2(1). https://doi.org/10.36985/manajemen.v2i1.365

Taylor, M. J., \& England, D. (2006). Internet marketing: Web site navigational design issues. Marketing Intelligence and Planning, 24(1). https://doi.org/10.1108/02634500610641570

Widodo, A., Riandi, \& Supriatno, B. (2015). Pengembangan Paket Program Coaching Berbasis Video Untuk Peningkatan Kompetensi Mengajar Guru Sains. Jurnal Cakrawala Pendidikan, 1(1). https://doi.org/10.21831/cp.v1i1.4191 